\title{
Arable and forest land user rent in a peri-urban district, Ghana
}

\author{
Divine Odame Appiah • Emmanuel Mawuli Abalo (iD) Gabriel Eshun
}

Published online: 1 July 2019

(C) The Author(s) 2019

\begin{abstract}
Land-use policies meant to mitigate deforestation activities in Ghana will have to consider the heterogeneity of the drivers of arable and forest land degradation. This would help avoid the one-size fits all approach to solving this problem. The urgency for this realisation is premised on the recent increasing monetary incentive to convert arable and forest land to other land uses in peri-urban Ghana. This study hypothesised that there is no significant relationship between land rent and the conversion probability from arable and forest land to other land uses such as commercial, industrial and residential land uses in Bosomtwe, a peri-urban district in the Ashanti region of Ghana. Four-hundred and one usufruct or landowning households and individual landowners participated through a three-stage sampling procedure. The results indicated a significant relationship between
\end{abstract}

D. O. Appiah · E. M. Abalo $(\bowtie)$ · G. Eshun

Department of Geography and Rural Development,

Kwame Nkrumah University of Science and Technology,

Kumasi, Ghana

e-mail: dodameappiah@gmail.com

E. M. Abalo

e-mail: emmanuel.abalom@gmail.com

G. Eshun

e-mail: gabriel_eshun_knust@yahoo.co.uk

E. M. Abalo

Environmental Change Institute, School of Geography and the Environment, University of Oxford, South Parks Road, Oxford OX1 3QY, UK higher land rent and conversion probability from arable land to other land uses such as commercial, industrial and residential land uses. Specifically, receiving land rent above $\mathrm{GH} \phi 400(\mathrm{OR}=1.979)$ predicted the outcome variable in all three models. Moreover, being a female $(\mathrm{OR}=0.612)$, ageing: 56 and $65(\mathrm{OR}=2.158)$ and 76 and above $(\mathrm{OR}=$ 11.781), traders/food vendors $(\mathrm{OR}=0.423)$ and widows $(\mathrm{OR}=2.050)$ had some odds of predicting the outcome variable. The study recommends a reformation of government land use conversion policies and decisions in collaboration with landowners, to include parameters which assess the effect and benefits of land conversion decisions on biodiversity before leasing out land rights.

Keywords Forest land tenure - User rent . Conversion - Arable land - Land uses - Bosomtwe . Ghana

\section{Introduction}

Forests play an important role in maintaining and balancing the natural ecosystem (Quacou 2016) by sequestering nearly 3 billion tons of anthropogenic carbon emissions annually (Canadell et al. 2007; FAO 2005). In monetary terms, the function performed by forested ecosystem as a carbon sink could be worth 
hundreds of billions of dollars compared to an equivalent sink created through artificial carbon capture and storage (Canadell and Raupach 2008; Jackson and Baker 2010). Deforestation and forest degradation disrupt the structure, function and role performed by the forest ecosystem and future food production (Francis et al. 2012). Both natural (Abalo et al. 2017a; Steffen et al. 2011; Lambin and Geist 2005) and anthropogenic factors (Abalo et al. 2017a; Steffen et al. 2011; Appiah et al. 2009) contribute to the complex phenomenon of land-use and land-cover changes (LULCC) in advanced and low-and-middleincome countries (LMICs). In recent years, pricing of natural resources has gained international recognition as an important economic principle capable of ensuring the sustainability of the forest ecosystem (Engel et al. 2008; Pirard 2012). Meanwhile, the pricing of these resources is driving forest conversion decision in most LMICs, a situation which does not augur well for forest sustainability due to the monetary incentive for land (Serneels and Lambin 2001; Vatn 2014).

Located within the sub-Saharan Africa region with a conducive climate and vast arable land, the forest ecosystem in Ghana provides many products on which the local population subsists (Appiah et al. 2009). The recent reduction of the forest ecosystem to Ghana's gross domestic product (GDP) (Forestry Commission of Ghana 2010) commensurate with the drastic reduction in the resource from 8.4 million hectares (1900) (Hawthorne 1989; Quacou 2016) to 665, 000 ha (2017) (Global Forest Watch 2018) at an annual rate of 3\% (IUCN 2006; Forestry Commission of Ghana 2017). This development has dire implications on the sustainability of the forest resource (Brundtland Commission 1987) and demands exigent steps to salvage the remaining natural forest in the country (Blay et al. 2007; Appiah et al. 2009; Abalo et al. 2017a).

The Bosomtwe District, Ashanti Region, is one of the districts with vast arable land and natural resources (GSS 2014a). The district has different species of tropical hardwood such as Wawa (Triplochiton scleroxylon), Denya (Cylicodiscus gabunensis), mahogany (Khaya ivorensis), Asanfena (Aningeria spp.), and Onyina (Ceiba pentandra) which have high economic value necessary for the development of the district. The forest has great potential for climate change mitigation through the REDD+ mechanism (Appiah et al. 2016). Meanwhile, the proximity of the district to the Kumasi Metropolis as well as its tourism potential, particularly from the Lake Bosomtwe resort, have encouraged the growth of newer settlements as well as local and foreign investments in infrastructure development (Appiah et al. 2014). These activities coupled with the increasing population of the district (GSS 2014a) with the consequence of increased food production (extensive farming activities) and its outlying areas have contributed to the degradation of the forest into a mosaic of secondary forest and thickets (GSS 2014a; Appiah et al. 2016). Despite the continual reduction in forest resources in the Municipality, existing empirical evidence seem to miss the underlying catalyst of deforestation in Bosomtwe district partly due to the complexity of LULCC and their interdependencies in social-ecological systems. Nonetheless, the more elaborate features such as agricultural activities, increased residential buildings, domestic wood-fuel consumption, and urbanisation have constantly been reported as the drivers of deforestation (GSS 2014a; Appiah et al. 2014, 2016; Appiah et al. 2017). Meanwhile, the human agent decisions, such as the economic incentive for money, which may be responsible for the conversion of the forest resources have largely been overlooked in these studies and the region at large (Peprah et al. 2017a, b; Abalo et al. 2017a). Without establishing the financial incentive and arable and forest land conversion decision linkage in the forest degradation discourse in the district, the micro-level dynamics driving forest degradation would only be subjected to untested hypotheses which could result in less favourable outcomes for planning deforestation policies and interventions in Bosomtwe district. This is important considering the recent qualitative findings by Peprah and colleagues which dispelled the assertion of the poor as agents of deforestation in Ashanti Region (Peprah et al. 2017a, b). The goal of this study is to ascertain this linkage and broaden our understanding of the drivers of land use changes in Ghana through a series of logistic regression models targeted at understanding the relationship between land rent and conversion probability decisions from arable land to other land uses such as commercial, industrial and residential land uses, amongst others in Bosomtwe district. 
Theoretical support

This paper draws from the application of the hedonic pricing principle (HPP) originally introduced in 1939 (Birch and Sunderman 2003) and the economic rent theory by Ricardo (1817). The basic theory of hedonic pricing is that the market value of a property can be expressed as a function of the value of a property's attributes in the aggregate. The principle also identifies that neighbourhood physical landscape and amenities determine the rent of the landed property (Nunns 2015; Rohani 2012). For all generally intended purposes, the HPP espouses that there are natural environmental characteristics which cannot be changed in an area or on a piece of land. These features are termed the non-produced characteristics, while there are other features, usually anthropogenic and known as structural features, with considerable elasticity to changes in response to the demand and supply conditions of the land and property market (Maddison 2000). The price of the land, $P$, is a function of both the non-produced and structural characteristics, q. This can be expressed by the hedonic price equation, $\mathrm{P}=\mathrm{f}$ (q1, q2, q3...qn). The assumption holds that no individual can influence the conditions of the hedonic price equation (HPE). However, the hedonic price schedule is determined by the interaction at equilibrium, of demand and supply for the land. The HPE can explicitly be expressed as:

$$
\begin{aligned}
P_{i t}= & b_{1} \ln S_{i t}+b_{2} \ln L_{i t}+c_{1} Q_{1 i}+c_{2} Q_{2} \\
& +c_{2 i} \cdots+c T Q T_{i}+\varepsilon_{i}
\end{aligned}
$$

where $P_{i t}$ is the transaction price of a property; $S_{i t}$ and $L_{i t}$ are the property's attributes; $b$ is the coefficient for the respective characteristic; $Q$ is a variable depicting the period of the sale, and $c$ is the time period's coefficient. Further, in the context of land use and price determinants by proximate characteristics in the Bosomtwe district, the HPE could be appropriated as follows:

$P_{\text {avg } i}=\alpha+\beta C_{i}+\sum_{j=1}^{k} \gamma_{j} N P_{j i}+\sum_{l=1}^{m} \delta_{l} S_{l i}+\varepsilon_{i}$

where the $\mathrm{C}$ is the combined land features, $\mathrm{NP}_{j i}$ is the non-produced features and the $\mathrm{S}_{l i}$ being the structural features. The $\alpha, \beta, \gamma$ and $\delta$ are the coefficients of respective land features. Here, the dependent variable, $P_{\text {avg } i}$, is the average price of a parcel of land (dependent on the size dimension) $i$, as reported by respondents. The range for $P_{\text {avg } i}$ in our dataset is the US $\$ 22.00$ to the US $\$ 4348.00$, with a mean value of US $\$ 4019.00$ at USD $1.00=\mathrm{GH} \phi 4.17$ (asat the time of data collection in 2016 and adjusted for inflation to $\mathrm{GH} \phi 5.2$ as of June 2019). The weighted average of each or the combined characteristics aggregated for each parcel of land had varying propensities of attracting higher values (Smith et al. 2016).

In the peri-urban fringe, the value of the land is dictated by its various competing uses, unlike in the rural milieu, where demand is for limited use, usually agriculture and agroforestry. The variety of peri-urban land uses is magnified due to the continuous modification of the use of a property. This assertion is in tandem with Koundouri and Pashardes (2000) that at a location with mixed proxy determinants of land rent, there is the need to assess the strength of the positive attributes that outweigh the adverse tendencies on the rent. Based on this assessment, it is instructive to correct these negatives. Without these amendments, however, the land would appear extrinsically significantly positive, while, it would present some intrinsically negative attributes to warrant any economic value. This would, in turn, affect even, the value of agricultural land in the process.

Recognising the fact that other factors are the driving force behind the value of land parcels, hedonic models were created to determine whether the value of a rural property primarily used for agriculture purposes hold potential for the future land markets under changing land use policy scenarios (O'Donoghue et al. 2015). These models focused on the size and soil characteristics of the land as these relate to the total surface area that can be used for crop production. Hence, the variable considered as salient is the rent of the land, as pertains in one breath and the future economic value of the land as anticipated by the rational agents in the long run (Hayrullahoğlu et al. 2018). This is underpinned by the general assumption that there are proximate variables with varying characteristics that would influence the hedonic pricing of the land in a location (Reydon et al. 2014).

Even though anthropogenic activities in the Bosomtwe district such as deforestation, besides natural causes, drives land use changes, the price of land could be a determining factor in the recent forest 
conversion probabilities in the district (Chakir and Lungarska 2015). This is because, since the supply of land is fixed in the short-run, the price of land, or the rent for its use, depends ultimately on demand for it (Ricardo 1817). The recent upsurge interest for land in the district could be attributed to its price becoming lucrative for landowners and investors. Hence, Ricardo's theory on economic rent (which need to be determined a posterior) of the said land was adopted for this study considering its direct relationship in explaining circumstances under which land will be converted from its original state to other land use patterns. Whereas switching forest land to other urban uses or land development is described as the most profitable land conversion in relation to land rent (Guiling et al. 2009), these conversions in the Municipality has the tendencies to cause the land use tradeoff between agrarian and forest land uses as well as for commercially driven demand. These tendencies have their own adverse cost implications on both the natural and social environment. For the natural environmental cost, pristine habitats stand the chance of being changed and converted permanently into some land uses that have greater irreversibility potential. On the social front, this would create the opportunity for the powerful elites particularly from the urban core of Kumasi to acquire land resources in Bosomtwe, a predominantly rural but progressively peri-urban district, at the expense of the smallholder farmers; this exhibit the inclination to generate a sense of property dispossession and livelihood disengagement of the greater vulnerable poor smallholder farmer majority. Institutional control of land use and its conversions must be strengthened, considering the current trajectories of developments.

\section{Methods}

Study context and design

The study took place in the Bosomtwe District, located in the central part of the Ashanti Region (Fig. 1). Typical of a semi-deciduous rainforest vegetation region, the district has two well-defined rainfall seasons: the main season, which occurs from March to July and the minor season, which starts from September to November with a peak in October. Deforestation is poised to increase given the projected future demand for agricultural land, coupled with the huge tourism potential of the district, notwithstanding the failed attempts by the government to curb the current spate of deforestation in the district (GSS 2014a).

The study adopted an inferential cross-sectional study design in which a 'snapshot' of the total population was taken, and the prevalence of land use and land cover changes were ascertained at a given point in time although recruitment of respondents spanned for a longer period (Sedgwick 2014). Adopting this design, the extent of arable land conversion and associated factors facilitating the conversion rate in the municipality were assessed (Abalo et al. 2017a).

Sampling techniques and research procedure

A three-stage sampling technique was used in this study. Criterion sampling technique was used to select a study district that has current and projected increase in deforestation (GSS 2014a; Palys 2008). In line with the demarcation of communities in the district based on the categorisation by the Ghana Statistical Service, fourteen communities were randomly sampled from twenty communities (GSS 2014a). Household respondents were systematically sampled in the study communities due to the absence of a coherent numbering system. Using this technique, 401 respondents; 201 usufruct households and 200 individual landowners, were sampled. The randomness of the sampling technique and homogeneity of the study participants helped to ensure the generalisability of the study findings (Tashakkori and Teddlie 2003).

Questionnaires were used to elicit participants' view on the study topic and this ensured reductionism and replicability of the study findings (Patton 2002). Information sought included participants' demographic characteristics: gender, age, educational level, marital status, size of household, occupation, average monthly income and category of respondents, "the criteria in determining the grounds rent per plot of land' 'reasons for converting original land uses to other uses' and 'observed patterns of land use conversion in the district'. Participants' demographic information were covariates and used in assessing their effect on the dependent variable: whether respondents had ever converted their arable land to other land-uses in the past 12 months', with options [code] 'No, I have not [0]' or 'Yes, I ever have [1]'. 


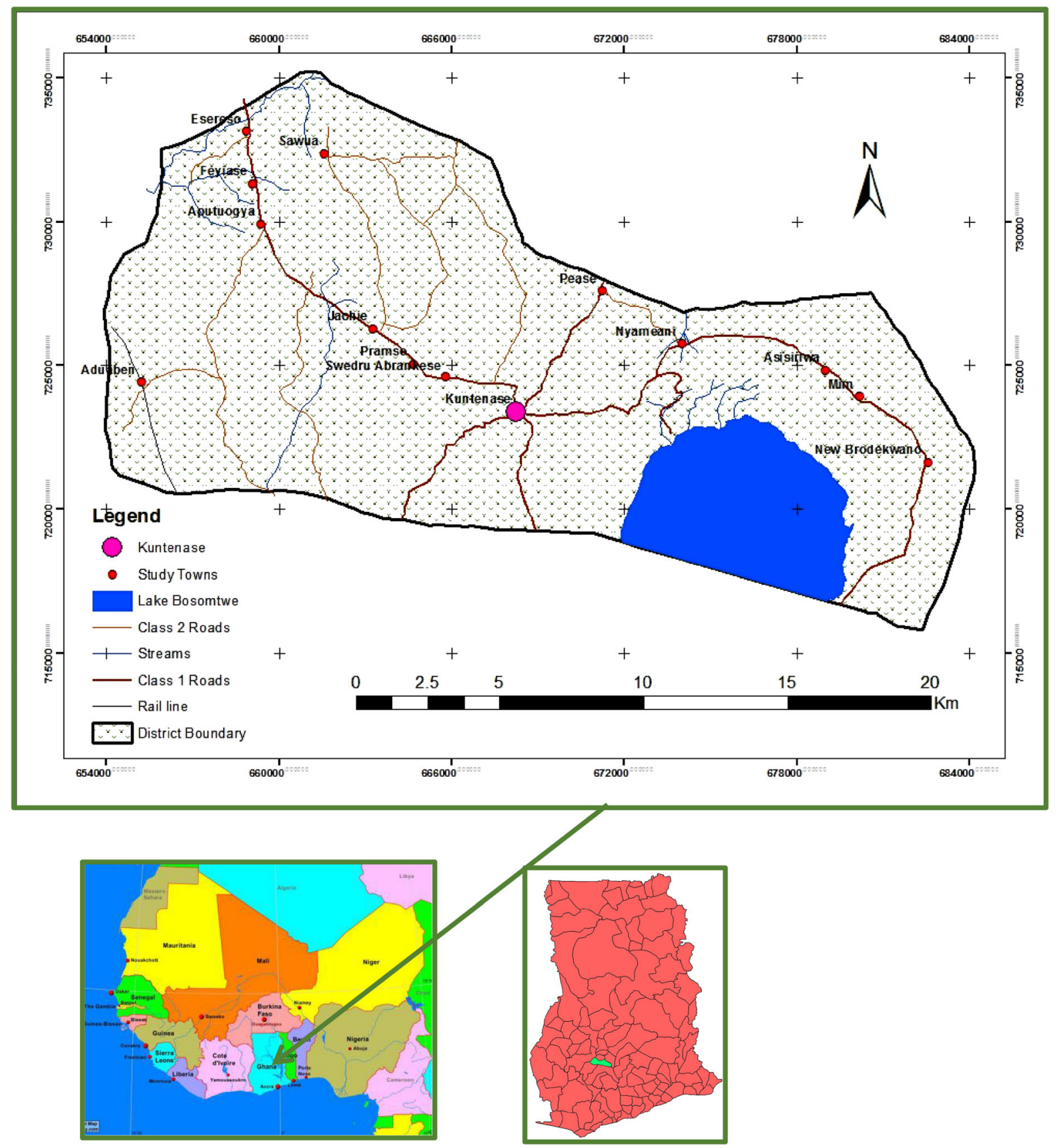

Fig. 1 Map of the study area showing the study communities

The main independent variable was 'land rent per plot of land (e.g. either $70 \times 100 \mathrm{~m} ; 80 \times 100 \mathrm{~m}$; or $100 \times 100 \mathrm{~m})^{\prime}$.
Data management and analysis

Data were analysed descriptively and inferentially using the Predictive Analytics SoftWare (PASW) version 16. Demographic characteristics were presented using population score, mean and standard 
deviation. A series of logistic regression analyses were conducted. In the first Model, the dependent variable and respondents' demographic characteristics were regressed individually on the independent variable thus calculating the crude odds ratio (OR) for each bivariate analysis. Logistic regression analysis was then conducted for the remaining two models. In Model 2, the OR in Model 1 were adjusted and regressed upon the dependent variable. In the final model, the OR in Model 2 was adjusted, and new covariates introduced into the model: 'the criteria in determining the grounds rent per plot of land' 'reasons for converting original land uses to other uses' and 'observed patterns of land use conversion in the district'. With the aid of the Nagelkerke $R^{2}$ and Hosmer-Lemeshow model fit-test, the goodness-of-fit of the model was judged (Nagelkerke 1991): a value of $p<0.05$ means the measure is not a good fit, whereas a value of $p>0.05$ is an indication of a good fit.

Ethical consideration

Participants were officially informed about the study through a field introductory letter presented by the authors through the Department of Geography and Rural Development. Besides this, oral consent was sought from the participants and the importance of the study to the district was explained to them. Participation in the study was purely voluntary and no names were recorded on the questionnaire.

\section{Result}

Background characteristics

Overall, 401 respondents comprising 200 individual landowners and 201 usufruct land users participated in the study. Majority of the study participants were females $(262,65.3 \%)$, in the 36-45 age bracket (91, $22.7 \%$ ), had basic education $(217,54.1 \%)$, were married $(228,56.9 \%)$, had a household size of 1-5 $(251,62.6 \%)$, were farmers $(193,48.1 \%)$ and had an average monthly income of not more than $\mathrm{GH} \phi 300$ $(179,44.6 \%)$. The standard variations for gender $(\sigma=0.476)$ and average monthly income $(\sigma=0.938)$ indicates that both variables are more clustered about their mean in relation to the other variables: target population, age, educational level, marital status and household size, though these are also clustered about their mean. However, the value for occupation $(\sigma=2.592)$ indicates a spread out of the data from the mean (Table 1).

Land rent and land use conversion

The bivariate analysis in Model 1 shows that participants who had received land rent per plot of land more than GH $\not 400$ were $97.9 \%$ more likely to have converted their arable land to other land uses in the past 12 months. Furthermore, females $(\mathrm{OR}=0.612)$, participants aged between 56 and 65 years $(O R=2.158)$ and 76 years and above $(\mathrm{OR}=11.781)$, widows $(\mathrm{OR}=2.050)$ and traders/food vendors $(\mathrm{OR}=0.423$ ) had odds of positively predicting the outcome variable. Adjusting for the OR in Model 1, respondents who had ever received land rent value more than $\mathrm{GH} \phi 400$ ( $\mathrm{AOR}=2.303)$, the oldest old $(76+)(\mathrm{AOR}=17.623)$, those with basic educational status $(\mathrm{AOR}=2.123)$ and individuals who received an average monthly income between $\mathrm{GH} \phi 301$ and $\mathrm{GH} \phi 399$ $(\mathrm{AOR}=2.268)$ had odds of predicting the outcome variable significantly, in Model 2 (Table 2).

After introducing the following variables in Model 3 ; determinants of land rent per plot of land, patterns of land use conversions and reasons for converting original land uses, respondents who had received in excess of $\mathrm{GH} \phi 400$ as land rent ( $\mathrm{AOR}=2.050$ ), those aged $76+(\mathrm{AOR}=19.061)$, had basic education ( $\mathrm{AOR}=2.389)$ and had received an average monthly income between $\mathrm{GH} \notin 301$ and $\mathrm{GH} \notin 399$ (AOR = 2.958) were significant predictors of the outcome variable. In all the Models, the odds of converting arable land with respect to the land rent value increased as more variables were introduced. Perhaps, this significant increase in the desire to convert arable land to other land uses could be partly attributed to the absolute values of land rent as depicted in Table 3.

Moreover, respondents who cited the patterns of land use conversions in the municipality as including either one of these; from agricultural land use (LU) to residential and/or commercial LU and from forest cover to residential or recreational LU, significantly predicted the outcome variable (AOR $=4.401$ ). In both bivariate and binary logit models, the average land rent received per plot of land and the oldest old (76 + years) were functions of arable land conversions in the past 12 months. The Hosmer and Lemeshow test result for Models 2 and 3 indicates that the model is a good fit. For 
Table 1 Demographic characteristics of respondents

\begin{tabular}{|c|c|c|c|c|}
\hline \multirow[t]{2}{*}{ Categories } & \multirow[t]{2}{*}{ Response } & \multicolumn{3}{|c|}{ Population share } \\
\hline & & $\mathrm{N}=401(\%)$ & $\mu$ & $\sigma$ \\
\hline \multirow[t]{2}{*}{ Target population } & Individual landowner & $200(49.9)$ & 2.0025 & 1.00125 \\
\hline & Usufruct or land-owning households & $201(50.1)$ & & \\
\hline \multirow[t]{2}{*}{ Gender } & Male & $139(34.7)$ & 1.6534 & 0.47649 \\
\hline & Female & $262(65.3)$ & & \\
\hline \multirow[t]{6}{*}{ Age (in years) } & $20-35$ & $77(19.2)$ & & \\
\hline & $36-45$ & $91(22.7)$ & 3.1895 & 1.64742 \\
\hline & $46-55$ & $61(15.2)$ & & \\
\hline & $56-65$ & $64(16)$ & & \\
\hline & $66-75$ & $67(16.7)$ & & \\
\hline & $76+$ & $41(10.2)$ & & \\
\hline \multirow[t]{4}{*}{ Educational level } & No formal education & $122(30.4)$ & & \\
\hline & Basic & $217(54.1)$ & 2.4963 & 1.19189 \\
\hline & SHS/tech/vocational & $37(9.2)$ & & \\
\hline & Tertiary/post-sec & $25(6.2)$ & & \\
\hline \multirow[t]{4}{*}{ Marital status } & Married & $228(56.9)$ & & \\
\hline & Single & $47(11.7)$ & 1.8429 & 1.07366 \\
\hline & Widow/widower & $87(21.7)$ & & \\
\hline & Divorced & $39(9.7)$ & & \\
\hline \multirow[t]{5}{*}{ Size of household } & $1-5$ people & $251(62.6)$ & & \\
\hline & 6-10 people & $99(24.7)$ & 1.6359 & 1.07103 \\
\hline & $11-15$ people & $21(6.2)$ & & \\
\hline & 16-20 people & $6(1.5)$ & & \\
\hline & $21+$ people & $24(6)$ & & \\
\hline \multirow[t]{4}{*}{ Occupation } & Farming & $193(48.1)$ & & \\
\hline & Public/civil servant & $36(9)$ & 3.6060 & 2.59217 \\
\hline & Trading/food vending & $89(22.2)$ & & \\
\hline & Artisans & $83(20.7)$ & & \\
\hline \multirow[t]{3}{*}{ Average monthly income } & Up to $\mathrm{GH} \notin 300$ & 179 (44.6) & 1.9850 & 0.93796 \\
\hline & Up to $\mathrm{GH} \notin 399$ & $49(12.2)$ & & \\
\hline & More than $\mathrm{GH} \phi 400$ & $173(43.1)$ & & \\
\hline
\end{tabular}

both cases, the models had a $23.7 \%$ and $29.7 \%$ measure of the success of predicting the dependent variable from the independent variables.

\section{Discussion}

The study assessed the influence of land rent value on arable land conversion decisions among usufruct or land-owning households and individual landowners in the Bosomtwe District, Ashanti region, Ghana. The study findings suggest a positive relationship between land rent and conversion probability from arable land to other land uses such as commercial, industrial and residential land uses, amongst others since the monetary incentive for land influenced arable land conversion decisions of the study participants. Although agriculture is the mainstay of most rural inhabitants in Ghana (GSS 2014a; Abalo et al. 2017a; Peprah et al. 2017a), and land possession and/or acquisition is 
Table 2 Logistic regression (ORs and 95\% CI) for the association of land rent per land and decisions to convert arable land to other land uses

\begin{tabular}{|c|c|c|c|c|c|c|}
\hline \multirow[t]{2}{*}{ Variables } & \multicolumn{2}{|c|}{ Model $1^{\mathrm{a}}$} & \multicolumn{2}{|c|}{ Model $2^{b}$} & \multicolumn{2}{|c|}{ Model $3^{\mathrm{c}}$} \\
\hline & OR & 95\%C.I & OR & 95\%C.I & OR & 95\%C.I \\
\hline \multicolumn{7}{|l|}{ Land rent per plot of land } \\
\hline Up to $\mathrm{GH} \phi 300$ & 1 & & 1 & & 1 & \\
\hline Up to $\mathrm{GH} \notin 399$ & 0.546 & $0.041-5.445$ & 0.107 & $0.005-2.421$ & 0.062 & $0.001-3.566$ \\
\hline More than $\mathrm{GH} \phi 400$ & $1.979 *$ & $1.159-3.379$ & $2.303^{*}$ & $1.223-4.337$ & $2.050^{*}$ & $1.066-3.943$ \\
\hline \multicolumn{7}{|l|}{ Gender } \\
\hline Male & 1 & & 1 & & 1 & \\
\hline Female & $0.612 *$ & $0.392-0.955$ & 0.596 & $0.334-1.063$ & 0.628 & $0.342-1.154$ \\
\hline \multicolumn{7}{|l|}{ Age in years } \\
\hline $20-35$ & 1 & & 1 & & 1 & \\
\hline $36-45$ & 0.618 & $0.333-1.145$ & 0.744 & $0.368-1.503$ & 0.715 & $0.344-1.484$ \\
\hline $46-55$ & 0.813 & $0.410-1.614$ & 0.927 & $0.420-2.046$ & 0.891 & $0.379-2.098$ \\
\hline $56-65$ & $2.158 *$ & $1.018-4.572$ & 2.449 & $0.950-6.315$ & 1.949 & $0.721-5.270$ \\
\hline $66-75$ & 1.015 & $0.516-1.996$ & 1.360 & $0.553-3.347$ & 1.108 & $0.425-2.886$ \\
\hline $76+$ & $11.781 *$ & $2.645-52.479$ & $17.623 *$ & $3.276-94.805$ & $19.061 *$ & $3.428-105.986$ \\
\hline \multicolumn{7}{|l|}{ Educational level } \\
\hline No formal education & 1 & & 1 & & 1 & \\
\hline Basic & 1.005 & $0.633-1.596$ & $2.123 *$ & $1.151-3.916$ & $2.389 *$ & $1.247-4.577$ \\
\hline Senior high sch/technical/vocational & 1.041 & $0.482-2.248$ & 1.213 & $0.441-3.337$ & 1.254 & $0.429-3.668$ \\
\hline Tertiary/post sec & 1.786 & $0.664-4.805$ & 1.133 & $0.277-4.632$ & 1.127 & $0.256-4.973$ \\
\hline \multicolumn{7}{|l|}{ Marital status } \\
\hline Married & 1 & & 1 & & 1 & \\
\hline Single & 1.151 & $0.600-2.208$ & 1.260 & $0.574-2.767$ & 1.521 & $0.666-3.471$ \\
\hline Widow/widower & $2.050 *$ & $1.173-3.582$ & 1.643 & $0.783-3.448$ & 1.749 & $0.789-3.878$ \\
\hline Divorced & 1.304 & $0.637-2.671$ & 1.133 & $0.478-2.687$ & 1.178 & $0.487-2.845$ \\
\hline \multicolumn{7}{|l|}{ Size of household } \\
\hline $1-5$ people & 1 & & 1 & & 1 & \\
\hline 6-10 people & 1.118 & $0.684-1.827$ & 1.035 & $0.591-1.810$ & 1.296 & $0.719-2.336$ \\
\hline $11-15$ people & 1.789 & $0.634-5.045$ & 0.894 & $0.278-2.880$ & 1.105 & $0.327-3.727$ \\
\hline 16-20 people & 0.559 & $0.111-2.827$ & 0.376 & $0.056-2.535$ & 0.573 & $0.073-4.516$ \\
\hline $20+$ people & 0.783 & $0.334-1.834$ & 0.745 & $0.277-2.002$ & 1.190 & $0.413-3.426$ \\
\hline \multicolumn{7}{|l|}{ Occupation } \\
\hline Farming & 1 & & 1 & & 1 & \\
\hline Public/civil servant & 1.961 & $0.814-4.722$ & 2.821 & $0.815-9.764$ & 3.115 & $0.827-11.737$ \\
\hline Trading/food vending & $0.423 *$ & $0.253-0.707$ & 0.508 & $0.252-1.025$ & 0.528 & $0.250-1.116$ \\
\hline Artisans & 1.098 & $0.629-1.918$ & 1.477 & $0.733-2.975$ & 1.725 & $0.829-3.588$ \\
\hline \multicolumn{7}{|l|}{ Average monthly income } \\
\hline Up to $\mathrm{GH} \notin 300$ & 1 & & 1 & & 1 & \\
\hline Up to $\mathrm{GH} \notin 399$ & 1.460 & $0.732-2.912$ & $2.268 *$ & $1.035-4.969$ & $2.958 *$ & $1.320-6.626$ \\
\hline More than $\mathrm{GH} \phi 400$ & 1.072 & $0.694-1.657$ & 1.255 & $0.741-2.127$ & 1.132 & $0.645-1.989$ \\
\hline \multicolumn{7}{|c|}{ Determinants of land rent per plot of land 1} \\
\hline The accessibility by roads & & & & & 1.517 & $0.901-2.556$ \\
\hline
\end{tabular}


Table 2 continued

\begin{tabular}{|c|c|c|c|c|c|c|}
\hline \multirow[t]{2}{*}{ Variables } & \multicolumn{2}{|l|}{ Model $1^{\mathrm{a}}$} & \multicolumn{2}{|c|}{ Model $2^{b}$} & \multicolumn{2}{|c|}{ Model $3^{c}$} \\
\hline & OR & 95\%C.I & OR & 95\%C.I & OR & 95\%C.I \\
\hline Found in the serviced area & & & & & 1.923 & $0.825-4.481$ \\
\hline \multicolumn{7}{|l|}{ Litigation free } \\
\hline \multicolumn{7}{|l|}{ Patterns of land use conversion } \\
\hline From agric LU to residential/commercial LU & & & & & 1 & \\
\hline From forest cover to residential/recreational LU & & & & & 1.582 & $0.868-2.885$ \\
\hline All conversions & & & & & $4.401 *$ & $1.990-9.734$ \\
\hline \multicolumn{7}{|l|}{ Reasons for converting original land use } \\
\hline New land uses are becoming profitable & & & & & 1 & \\
\hline Original land uses are more than new LUs & & & & & 1.187 & $0.601-2.345$ \\
\hline Plenty of land available for the conversion & & & & & 0.844 & $0.477-1.494$ \\
\hline \multicolumn{7}{|l|}{ Model fitting information } \\
\hline Log-likelihood & \multicolumn{2}{|l|}{512.633} & \multicolumn{2}{|c|}{444.395} & \multicolumn{2}{|c|}{422.599} \\
\hline Hosmer-Lemeshow $\chi^{2}$ & \multicolumn{2}{|l|}{0.000} & \multicolumn{2}{|c|}{$0.670(5.797)$} & \multicolumn{2}{|c|}{$0.177(11.451)$} \\
\hline Nagelkerke Pseudo- $R^{2}$ & \multicolumn{2}{|l|}{0.025} & \multicolumn{2}{|c|}{0.237} & \multicolumn{2}{|c|}{0.297} \\
\hline
\end{tabular}

(1): Are the reference categories

$* p<0.05$

${ }^{a}$ Unadjusted odds ratio (OR) in Model 1

${ }^{\mathrm{b}}$ Adjusted odds ratio (AOR) in Model 1

${ }^{\mathrm{c}}$ Adjusted OR Model 2 plus 'the criteria in determining the grounds rent per plot of land' 'reasons for converting original land uses to other uses' and 'observed patterns of land use conversion in the district'

Table 3 Absolute values for land rent per plot of land

\begin{tabular}{lcccc}
\hline Rent value (in GH $\phi$ ) & Rent in UDS & Rent in UDS & Frequency $(\mathrm{N}=401)$ & Percent \\
\hline 100 & 19 & 19.23077 & 31 & 6.3 \\
200 & 37 & 38.46154 & 23 & 5.8 \\
300 & 56 & 57.69231 & 18 & 4.6 \\
400 & 74 & 76.92308 & 19 & 4.8 \\
500 & 93 & 96.15385 & 21 & 5.3 \\
600 & 111 & 115.3846 & 6 & 1.5 \\
700 & 130 & 134.6154 & 2 & 0.5 \\
1000 & 185 & 192.3077 & 10 & 2.5 \\
1500 & 278 & 288.4615 & 2 & 0.5 \\
2000 & 370 & 384.6154 & 69 & 17.5 \\
4000 & 741 & 769.2308 & 92 & 23.3 \\
6000 & 1111 & 1153.846 & 74 & 18.7 \\
8000 & 1481 & 1538.462 & 22 & 5.6 \\
9000 & 1667 & 1730.769 & 2 & 0.5 \\
10,000 & 1852 & 1923.077 & 9 & 2.3 \\
20,000 & 3704 & 3846.154 & 1 & 0.3 \\
\hline
\end{tabular}

deemed a valuable asset among smallholder farmers and individual landowners (Peprah et al. 2017b), the current study found contrary evidence among a predominantly agrarian community in which landowners willingly converted their arable land for a price of $\mathrm{GH} \not 400$ (\$77.00) or more. 
Whereas the base amount necessary to change the conversion decisions of the respondents seems 'small', the absolute values in Table 3 portray otherwise (between $\$ 19$ and \$3846). Perhaps, the pressing socio-economic demands in the study prefecture which necessitated the need for policymakers to suggest poverty reduction strategy to the Ghana government in the recent population and housing census, could be attributed to the recent penchant of landowners to seek alternate and 'easy' forms of income to cater for the needs of their families (GSS 2014a). The alternate and 'easy' way out of poverty for most landowners in the study communities are the land rent values offered to usufruct and individual landowners who for the most part, are farmers. Perhaps, solving the poverty problem of the study participants may not necessarily translate into reduction in the sale of arable land in the district considering the recent findings by Peprah and colleagues in Ashanti Region regarding the poor smallholder farmers as agents of deforestation through agricultural extensification (Peprah et al. 2017a). Considering the recent increase in the purchase of land and the aesthetic scenery of the study area which mostly serves as a pull factor for prospective land buyers, these occurrences do not augur well for the sustainability of the fragile ecosystem, biodiversity and conservation of the Bosomtwe basin where pristine forest resources are destroyed in the conversion process. The study findings, however, highlights the increasing value for rural agricultural properties which holds potential for the future land markets under changing land use policies scenarios (O'Donoghue et al. 2015).

Indeed, whereas the market-oriented reforms adopted by many low-and-middle-income countries (LMICs) in the 1980s and 1990s seem to have had an important role in altering land use patterns (Hettig et al. 2016), in recent times, micro-level demographic and economic indicators, such as income, gender, social status, etc., act as catalyst for the recent land conversion decisions among landowners in these countries. For instance, in this study, respondents' demographic characteristics such as gender, age and educational status and socio-economic status; widows, food vendors/traders and individuals receiving an average monthly income between $\mathrm{GH} \notin 301$ and GH $₫ 399$ (approx. \$56 and \$76), significantly predicted the conversion decisions of landowners. The aged; based on the healthy life index and old age in Ghana (WHO 2015; Abalo et al. 2018), were more likely to give up possession of their land for money. These group of people are not economically active (GSS 2014a) and perhaps, envisage the prospect of losing their land as a preferred choice: to cater for their immediate needs rather than keeping the land for the future generation and their children, who are mostly based in the cities in search of "greener pastures". Meanwhile, considering this development and the stimulating offers provided for land rent by land buyers, the need to sustain agrarian land and forest resources for use by both current and future generations within the study prefecture could be greatly compromised (Brundtland Commission 1987).

The study also found that the current changing land use patterns: from agricultural land use to residential/commercial land use and from forest cover to residential/recreational land use in the district influenced the conversion decisions of landowners (O'Donoghue et al. 2015). The recent conversion of arable land and forest land to residential land use patterns in the hitherto rural communities of the Ashanti Region is alarming (GSS 2014a; Abalo et al. 2017a). For the study area, this is could be due to the location and the socio-ecological functions of Lake Bosomtwe in the district and its proximity to the regional capital. Thus, giving land in the district the propensity to leverage on the hedonic properties of the Lake to increase the proportion of population influx into the district in search of land for various socioeconomic uses, hence underscoring the rapidity with which the district is being urbanised from a hitherto predominantly rural one. To accommodate the increasing population, hitherto forested areas and arable land are being cleared to make way for residential buildings (Abassa et al. 2018; CavigliaHarris and Harris 2011) and the Bosomtwe district is no exception due to its proximity to the regional capital. The study, however, contradicts recent occurrences in countries facing a decline in urban populations where farmers immediately convert their productive agricultural land into real estate and completely abandon the profession to not fall victim to falling land prices. Meanwhile, in other jurisdictions, specifically in developed countries, farmers retain their land and continue their profession even when the land prices decline, and suburbs shrink (Yagi and Garrod 2018). These distinct dichotomous 
scenarios highlight the changing phases and importance of geographical influence on the maintenance of agricultural land between the developed and developing countries.

That notwithstanding, the shift in the drivers of land use change identified in this study could imply that majority of landowners are may be shifting from agrarian subsistence to more diversified and nonagricultural livelihood activities within a changing economy. For instance, more than half (51.9\%) of the study participants were involved in non-agricultural livelihood activities as their primary occupation in a community which is known to be predominantly agrarian since 1960 (GSS 2014a). These changing dynamics brings to fore the need for policymakers to introduce sustainable, diversified and an enabling market for both agricultural and non-agricultural livelihood activities in the study district so that both parties would be incentivised to maintain their individual professions. Doing this would help avert situations whereby usufructs and individual landowners' resort to selling agricultural and forested land in exchange of 'easy' income and promote the sustainability of the forest ecosystem and the Bosomtwe basin (Yagi and Garrod 2018). Moreover, owing to the multi-functional values of agricultural and forested land (Zasada 2011), undertaking this initiative would ensure the viability of this complex yet important ecosystem for perpetuity and retain the benefits that agricultural land provide.

With respondent's demographic, economic and social status influencing land conversion decisions within the study area, the diverse physical environment, tourism potential and topography of the district's forest biome (Amuquandoh 2010) could exacerbate future land conversion possibilities thus defeating the government's investment and efforts at curbing deforestation in the region (GSS 2014a). With participants' enthusiasm to convert arable land high, perhaps due to poverty, the state of the forest ecosystem risk declining further and perhaps to a state where animal life, sustainability and natural functioning of the forest ecosystem as a carbon sink, could be compromised and become critical as found in the Ejisu-Juabeng Municipality (GSS 2014b; Abalo et al. 2017a). Our study has some limitations which are worth spelling out. The absence of dimension of time in cross-sectional studies meant that the study findings failed to establish causalities and directionality of analysis among the study variables. However, this seeming drawback was tackled by formulating a question that assessed the past of the study's thrust, and this helped to ascertain previous exposure although the information was collected at a single point in time. This was supported by the regression analysis which helps to predict future occurrences, a situation which cross-sectional studies often fail to do.

\section{Conclusion}

The study found that micro-level demographic and economic indicators were the catalyst for the recent land conversion decisions among landowners in the study prefecture. Cardinally, the incentive for money was a major driver of LULCC in the study area. The tourism potential in the study prefecture, accentuated by the presence of the Lake Bosomptwe, could be responsible for the recent increase in conversion decision of arable and forest landowners and interest of real estate agents in the district. The increased number of hotels, guest houses and resort centres in response to the influx of people to the district for tourism thus increasing the hedonic propensities of land in the district calls for immediate remediation steps to salvage rapid rates of arable and forest cover depletion considering the ecological importance of the district in terms of the Lake ecosystem.

In view of these findings, the study recommends a reformation of government land use conversion policies and decisions to include parameters which assess the effect and benefits of land conversion decisions on biodiversity before leasing out land rights. To achieve this, the visions, goals and mission of real estate developers and other land buyers should be scrutinised to ascertain and differentiate among development policies with, and those without, detrimental effect on the sustainability of river basins, forest resources and the environment, without recourse to the financial incentive. These policies should incorporate the views and contribution of landowners since only $20 \%$ of land within the study area are statutorily vested in the state, whereas $80 \%$ are customarily-controlled by traditional chiefs and household heads. Should this prove tedious in the short-term, the seemingly controversial payment for ecosystem services (PES) could be adopted as an interim measure since the definition of property (land) rights in Ghana is easily defined, thus, making its 
introduction as a market environmentalist approach feasible. However, this ought to be implemented as a short-term approach with the former rather than the latter being the ultimate.

Open Access This article is distributed under the terms of the Creative Commons Attribution 4.0 International License (http:// creativecommons.org/licenses/by/4.0/), which permits unrestricted use, distribution, and reproduction in any medium, provided you give appropriate credit to the original author(s) and the source, provide a link to the Creative Commons license, and indicate if changes were made.FundFunding The West African Science Service Centre for Climate Change and Adapted Land Use (WASCAL) is acknowledged for the financial support for this work. We further thank the Departments of Geography and Rural Development of Kwame Nkrumah University of Science and Technology, Kumasi, Ghana for the use of office space and some utility services.

\section{References}

Abalo, E. M., Agyemang, S., Atio, S., Ofosu-Bosompem, D., Peprah, P., \& Ampomah-Sarpong, R. (2017a). Environmental sanitation unleashed: effectiveness and challenges of the national sanitation day as a community sanitation participatory approach in Aboabo, Ghana. Cogent Environmental Science, 3(1), 1405888.

Abalo, E. M., Mensah, C. M., Agyemang-Duah, W., Peprah, P., Budu, H. I., Gyasi, R. M., et al. (2018). Geographical differences in perceived health status among older adults in Ghana: Do gender and educational status matter? Gerontology \& Geriatric Medicine, 4, 1-9.

Abass, K., Adanu, S. K., \& Agyemang, S. (2018). Peri-urbanisation and loss of arable land in Kumasi Metropolis in three decades: Evidence from remote sensing image analysis. Land Use Policy, 72(2018), 470-479.

Amuquandoh, F. E. (2010). Residents' perceptions of the environmental impacts of tourism in the Lake Bosomtwe Basin, Ghana. Journal of Sustainable Tourism, 18(2), 223-238.

Appiah, D. O., Bugri, J. T., Forkuor, E. K., \& Boateng, P. K. (2014). Determinants of peri- urbanization and land use change patterns in Peri-Urban Ghana. Journal of Sustainable Development, 7(6), 95-109.

Appiah, D. O., Bugri, J. T., Forkuo, E. K., \& Yamba, S. (2016). Agricultural and forest land use potential for REDD + among smallholder land users in rural Ghana. International Journal of Forestry Research. https://doi.org/10.1155/ 2016/7218305.

Appiah, M., Blay, D., Damnyag, L., Dwomoh, F. K., Pappinen, A., \& Luukkanen, O. (2009). Dependence on forest resources and tropical deforestation in Ghana. Environment, Development and Sustainability, 11(3), 471-487.

Birch, J., \& Sunderman, M. (2003). Estimating price paths for residential real estate. The Journal of Real Estate Research, 25(3), 277-300.
Blay, D., Appiah, M., Damnyag, L., Dwomoh, F. K., Luukkanen, O., \& Pappinen, A. (2007). Involving local farmers in the rehabilitation of degraded tropical forests: Some lessons from Ghana. Environment, Development and Sustainability, 10(4), 503-518.

Brundtland Commission, G. H. (ed) (1987). Our common future: Report of the World Commission on Environment and Development, Oxford, UK: Oxford.

Canadell, F. G., \& Raupach, M. R. (2008). Managing forests for climate change mitigation. Science, 320, 1456.

Canadell, J. G., Le Quéré, C., Raupach, M. R., Field, C. B., Buitenhuis, E. T., Ciais, P. F., et al. (2007). Contributions to accelerating atmospheric $\mathrm{CO} 2$ growth from economic activity, carbon intensity, and efficiency of natural sinks. Proceedings of the National Academy of Sciences USA, 104, 18866.

Caviglia-Harris, J. L., \& Harris, D. W. (2011). The impact of settlement design on tropical deforestation rates and resulting land cover patterns. Agricultural and Resource Economics Review, 40, 451-470.

Chakir, R., \& Lungarska, A. (2015). Agricultural land rents in land use models: a spatial econometric analysis. In paper prepared for presentation at the 150th EAAE Seminar "The spatial dimension in analysing the linkages between agriculture, rural development and the environment". Jointly organised between Scotland's Rural College (SRUC) and Teagasc Scotland's Rural College, Edinburgh, Scotland October 22-23, 2015.

Engel, S., Pagiola, S., \& Wunder, S. (2008). Designing payments for environmental services in theory and practice: an overview of the issue. Ecological Economics, 65(4), 663-674.

FAO (Food and Agricultural Organization of the United Nations). (2005). FAO Statistical database 2005 available at http://faostat.fao.org/. Accessed 2 March 2019.

Forestry Commission of Ghana. (2010). Readiness Preparation Proposal Ghana. Submitted to Forest Carbon Partnership Facility (FCPF). Final, December 2010. http://www. forestcarbonpartnership.org/sites/forestcarbonpartnership. org/files/Documents/PDF/Jan2011/Revised_Ghana_RPP_2_Dec-2010.pdf Accessed 30 March 2018.

Forestry Commission of Ghana. (2017). Ghana's National Forest Reference level, National Redd + Secretariat. http://redd.unfccc.int/files/ghana_national_reference_ level_01.01_2017_for_unfccc-yaw_kwakye.pdf Accessed 30 March 2018.

Francis, C. A., Hansen, T. E., Fox, A. A., Hesje, P. J., Nelson, H. E., Lawseth, A. E., et al. (2012). Farmland conversion to non-agricultural uses in the US and Canada: current impacts and concerns for the future. International Journal of Agricultural Sustainability, 10(1), 8-24.

Ghana Statistical Service [GSS]. (2014a). 2010 Population and Housing Census. District Analytical Report, Bosomtwe District.

Ghana Statistical Service [GSS]. (2014b). 2010 Population and Housing Census. District Analytical Report, Ejisu-Juaben Municipal Assembly.

Global Forest Watch. (2018). Tree cover loss in Ghana. https:// www.globalforestwatch.org/dashboards/country/ GHA? widget=treeLoss\#treeLoss Accessed 28 October 2018. 
Guiling, P., Brorsen, B. W., \& Doye, D. (2009). Effect of urban proximity on agricultural land values. Land Economics, 85, 252-264.

Hawthorne, W. D. (1989). The flora and vegetation of Ghana's forests. In Ghana forest inventory proceedings (pp. 8-13). Overseas Development Agency/Ghana Forestry Department, Accra.

Hayrullahoğlu, G., Aliefendioğlu, Y., Tanrivermiş, H., \& Hayrullahoğlu, A. C. (2018). Estimation of the hedonic valuation model in housing markets: The case of Cukurambar region in Cankaya District of Ankara Province. Ecoforum, 7(1), 1-9.

Hettig, E., Lay, J., \& Sipangule, K. (2016). Drivers of households' land-use decisions: A critical review of micro-level studies in tropical regions. Land, 2016(5), 32.

IUCN. (2006). Forest landscape restoration to meet Ghana's deforestation Challenges, IUCN (http://www.IUCN.org/ en/news/archive/2006/newfebruary06.htm). Accessed 2 March 2019.

Jackson, R. B., \& Baker, J. S. (2010). Opportunities and constraints for forest climate mitigation. BioScience, 60(9), 698-707.

Koundouri, P., \& Pashardes, P. (2000). Hedonic price analysis and selectivity bias: Water salinity and demand for land. Department of Economics, Discussion Paper 2001-02, University of Cyprus, pp. 1-20.

Lambin, E. F., \& Geist, H. (Eds.). (2005). Land use and land cover change: Local processes, global impacts. New York, NY: Springer.

Maddison, D. (2000). A hedonic analysis of agricultural land prices in England and Wales. European Review of Agricultural Economics, 27(4), 519-532.

Nagelkerke, N. J. D. (1991). A note on a general definition of the coefficient of determination. Biometrika, 78(3), 691-692. https://doi.org/10.1093/biomet/78.3.691.

Nunns, P. (2015). The value of land, floor space, and amenities: A hedonic price analysis of Auckland property sales. In New Zealand Association of Economists Annual Conference 2015, Working Paper. MR Cagney Pty Ltd., p. 37.

O’Donoghue, C., Lopez, J., O’Neill, S., \& Ryan, M. (2015). Hedonic price model of self- assessed agricultural land values. In Paper prepared for presentation at the 150th EAAE Seminar jointly Organised between Scotland's Rural College (SRUC) and Teagasc Scotland's Rural College, Edinburgh, Scotland October 22-23, p. 20.

Palys, T. (2008). Purposive sampling. In L. M. Given (Ed.), The sage encyclopedia of qualitative research methods (Vol. 2, pp. 697-698). Los Angeles: Sage.

Patton, M. Q. (2002). Qualitative research and evaluation methods (3rd ed.). Thousand Oaks, CA: Sage.

Peprah, P., Abalo, E. M., Amoako, J., Nyonyo, J., AgyemangDuah, W., \& Adomako, I. (2017a). The reality from the Myth: The poor as main agents of forest degradation: Lessons from Ashanti Region, Ghana. Environmental \& Socio-economic Studies, 5(3), 1-11.

Peprah, P., Kyiyaga, E. M., Afful, H., Abalo, E. M., \& Agyemang-Duah, W. (2017b). Does the Ghanaian livelihood empowerment against the poverty programme lead to an increase in household productive livelihood assets? Analysing the Ashanti scenario. Cogent Social Sciences, 3(1), 1298174.

Pirard, R. (2012). Market-based instruments for biodiversity and ecosystem services: A lexicon. Environmental Science \& Policy, 19-20, 59-68. https://doi.org/10.1016/j.envsci. 2012.02.001.

Quacou, I. E. (2016). Unsustainable management of forests in Ghana from 1900-2010. International Journal of Environmental: Monitoring and Analysis, 4(6), 160-166.

Reydon, B. P., Plata, L. E. A., Sparovek, G., Goldszmidt, R. G. B., \& Telles, T. S. (2014). Determination and forecast of agricultural land prices. Nova Economia Belo Horizonte, 24(2), 389-408.

Ricardo, D. (1817). Principles of Political Economy and Taxation (3rd ed. 1821).

Rohani, M. (2012). Impact of Hauraki Gulf amenity on the land price of neighbourhood properties. An empirical Hedonic Pricing Method case study, North Shore, Auckland. Auckland Council Working Paper 2012/001.

Sedgwick, P. (2014). Cross-sectional studies: Advantages and disadvantages. BMJ, 348, g2276. https://doi.org/10.1136/ bmj.g2276.

Serneels, S., \& Lambin, E. F. (2001). Proximate causes of landuse change in Narok District, Kenya: a spatial statistical model. Agriculture, Ecosystems \& Environment, 85, 65-81.

Smith, R. A., McKinney, C. N., Caudill, S. B., \& Mixon, F. G., Jr. (2016). Consumer ratings and the pricing of experience goods: hedonic regression analysis of beer prices. Agricultural and Food Economics, 4(1), 24.

Steffen, W., Grinevald, J., Crutzen, P., \& McNeill, J. (2011). The anthropocene: Conceptual and historical perspectives. Philosophical Transactions of the Royal Society A: Mathematical Physical and Engineering Sciences, 369, 842-867.

Tashakkori, A., \& Teddlie, C. (Eds.). (2003). Handbook of mixed methods in social and behavioural research. Thousand Oaks, CA: Sage.

Vatn, A. (2014). Markets in environmental governance - From theory to practice. Ecological Economics, 105, 97-105.

World Health Organization [WHO]. (2015). Country statistics and global health estimates by WHO and UN partner. Geneva, Switzerland: Author. https://www.who.int/gho/ countries/gh.pdf. Accessed 2 March 2019.

Yagi, H., \& Garrod, G. (2018). The future of agriculture in the shrinking suburbs: The impact of real estate income and housing costs. Land Use Policy, 76, 812-822. https://doi. org/10.1016/j.landusepol.2018.03.013.

Zasada, I. (2011). Multifunctional peri-urban agriculture-a review of societal demands and the provision of goods and services by farming. Land Use Policy, 28(4), 639-648.

Publisher's Note Springer Nature remains neutral with regard to jurisdictional claims in published maps and institutional affiliations. 